\title{
Susceptibility profile of Brazilian Rhodococcus equi isolates against azithromycin, clarithromycin and erythromycin
}

\author{
Perfil de susceptibilidade de isolados brasileiros de Rhodococcus equi frente à azitromicina, \\ claritromicina e eritromicina
}

\author{
Letícia Trevisan Gressler ${ }^{I}$ Bibiana Petri da Silveira ${ }^{I}$ Marcelo Luís Schwab ${ }^{\mathrm{I}}$ \\ Agueda Castagna de Vargas $^{I}$ Luciana PötterII Sônia de Avila Botton ${ }^{I^{*}}$
}

- NOTE -

\section{ABSTRACT}

\begin{abstract}
Rhodococcus equi infection treatment is usually a macrolide (azithromycin - AZM, clarithromycin - CLR and erythromycin - ERY) and rifampicin combination. However, resistance cases have been reported, especially for ERY. In view of the need of a study about Brazilian isolates susceptibility profile, this study aimed to characterize the minimum inhibitory concentration (MIC) of the macrolides - AZM, CLR and ERY - against $44 \boldsymbol{R}$. equi isolates. It was found all isolates CLR and AZM sensitive; however, for ERY, 27\% (12/44) were classified as intermediate sensitivity. R. equi Brazilian isolates used here showed a large susceptibility profile, except against ERY, for which it was observed some resistance evidence. In order to avoid failures in the equine rhodococcosis therapy it was highlighted the importance of microbiological culture and antimicrobial susceptibility testing in vitro before beginning treatment.
\end{abstract}

Key words: macrolide, minimum inhibitory concentration, antimicrobial susceptibility, rhodococcosis.

\section{RESUMO}

No tratamento de infecções por $\boldsymbol{R}$. equi, usualmente emprega-se uma combinação de macrolideos (azitromicina - AZI, claritromicina-CLARI e eritromicina-ERI) e rifampicina. Todavia, casos de resistência frente a esses antimicrobianos vêm sendo reportados, especialmente à ERI. Tendo em vista a necessidade de um estudo sobre o perfil de susceptibilidade de isolados brasileiros, buscou-se verificar a concentração inibitória mínima (CIM) de AZI, CLARI e ERI frente a 44 isolados de $\boldsymbol{R}$. equi de diferentes origens. Todos os isolados analisados demonstraram perfil de sensibilidade à AZI e CLARI; em contraste, frente à ERI, 27\% (12/44) apresentaram sensibilidade intermediária. A fim de evitar falhas no tratamento da rodococcse equina, destaca-se a importância da cultura microbiológica e a realização de testes in vitro de susceptibilidade antimicrobiana de $\boldsymbol{R}$.equi antes do início do tratamento.
Palavras-chave: concentração inibitória mínima, macrolideos, susceptibilidade antimicrobiana, rodococose.

Rhodococcus equi is a gram-positive facultative and intracellular pathogen and etiologic agent of equine rhodococcosis (QUINN et al., 1994). The main clinical manifestation of rhodococcosis is pyogranulomatous bronchopneumonia in foals under six months of age (QUINN et al., 1994). This disease is responsible for large economic losses due to mortality, since pneumonia is a major cause of death in foals (GIGUÈRE et al., 2011). In vitro, $\boldsymbol{R}$. equi has to be sensitive to a wide variety of antibiotics, such as aminoglycosides, beta-lactams and second-generation of cephalosporins (GIGUÈRE et al., 2010). However, their ability to replicate in macrophages and neutrophils limited the therapeutic options to drugs able to penetrate in lipophilic environment (BUCKLEY et al., 2007).

In 1980 the combination of erithromicyn (ERY) and rifampicin become the treatment of equine rhodococcosis highly efficient and dramatically reduced the mortality in foals (GIGUERE et al., 2010). Since then, $R$. equi resistance to these drugs has been observed (BUCKLEY et al., 2007). In this respect, azithromycin (AZM) and clarithromycin (CLR) have been proposed as alternatives to ERY for the treatment of $\boldsymbol{R}$. equi infections in foals (JACKS et al., 2003). Furthermore, when compared with ERY theses drugs are chemically more stable, possess greater bioavailability and achieve

'Laboratório de Bacteriologia da Universidade Federal de Santa Maria (UFSM), Av. Roraima, 1000, 97105-900, Santa Maria, RS, Brasil.

E-mail: sabott20@gmail.com. *Corresponding author.

"Departamento de Zootecnia, UFSM, Santa Maria, RS, Brasil. 
higher concentrations in macrophages and neutrophils (JACKS et al., 2003). However, some studies have shown the emergence of strains resistant also to AZM and CLR. On the basis of the lack of data about Brazilian $\boldsymbol{R}$. equi isolates, this study aimed to characterize the minimum inhibitory concentration (MIC) of AZM, CLR and ERY against $44 \boldsymbol{R}$. equi isolates from different sources.

$\boldsymbol{R}$. equi were isolated from clinical $(\mathrm{n}=15)$, soil $(n=15)$, feces $(n=9)$ and installations $(n=5)$ samples. All those were collected at equine breeding farms, located in Rio Grande do Sul state, Brazil, between 1991 and 2013 year. Clinical samples were isolated from postmortem lung lesions in foals, feces samples were collected from healthy mares, soil samples were taken from paddocks and installations samples were collected from wall stables, drinkers and feeders. All isolates were characterized as $\boldsymbol{R}$. equi by phenotypic features (QUINN et al., 1994), and then confirmed genotypically according to MONEGO et al. (2009). All isolates remained lyophilized and stored at $-20^{\circ} \mathrm{C}$ until time of testing. The MIC tests were performed in Müeller-Hinton broth (MHB) medium (Himedia ${ }^{\circledR}$ Laboratories) using the microdilution method in accordance with the guidelines of the Clinical and Laboratory Standards Institute (CLSI, 2013). All microorganisms were cultured in MHB for $24 \mathrm{~h}$ aerobically at $37^{\circ} \mathrm{C}$. For each microorganism, an inoculum suspension was prepared in $0.9 \%$ saline, adjusted to the turbidity of 0.5 on the McFarland' scale, and absorbance readings were performed in a spectrophotometer at $600 \mathrm{~nm}$-wavelength. These suspensions were diluted in MHB and approximately $1 \times 10^{5} \mathrm{CFU} \mathrm{ml} \mathrm{m}^{-1}$ were inoculated into the microtiter plates. The antimicrobials (AZM, CLR and ERY) were tested at 0.03 up $128 \mu \mathrm{g} \mathrm{ml}^{-1}$. The standard strain, $R$. equi ATCC 33701, known to be sensitive to AZM, CLR and ERY, was used as quality control tests (GIGUÈRE et al., 2010). The MIC was defined as the lowest concentration of antimicrobials that inhibited the visible growth of $\boldsymbol{R}$. equi isolates after overnight incubation evidenced by the addition of $20 \mu \mathrm{L}$ of 2,3,5-triphenyltetrazolium chloride $\left(\right.$ Vetec $\left.^{\circledR}\right) 1 \%$. R. equi isolates were classified as sensitive $\left(\leq 2 \mu \mathrm{g} \mathrm{ml}^{-1}-\mathrm{AZM}\right.$ and CLR, and $\leq 0.5 \mu \mathrm{g} \mathrm{ml}^{-1}$ - ERY) or resistant $\left(\geq 8 \mu \mathrm{g} \mathrm{ml}^{-1}-\mathrm{AZM}, \mathrm{CLR}\right.$ and ERY) (CLSI, 2009). In addition, isolates with MIC values between the concentrations mentioned above were classified as intermediate sensitivity. All of the susceptibility tests were performed using at least three biological replicates and two technical replicates. The Kruskal-Wallis test was employed to calculate the association among antimicrobials MIC and the source of the isolates and the year of sample collection. The Bonferroni test was used to calculate the media when it was observed differences. The minimum significance level considered was $\mathrm{P}<0.05$. The data were analyzed by SAS statistical software.

Among the $44 \boldsymbol{R}$. equi isolates evaluated, none was resistant for antimicrobials tested. All isolates were sensitive against AZN and CLR, with media MIC value of $0.49 \mu \mathrm{g} \mathrm{ml}^{-1}$ and $0.11 \mu \mathrm{g} \mathrm{ml} \mathrm{m}^{-1}$, respectively. However, $27 \%$ (12/44) of $\boldsymbol{R}$. equi isolates were classified as intermediate sensitivity for ERY, with media MIC value of $0.54 \mu \mathrm{g} \mathrm{ml}^{-1}$. This result for ERY can be explained by its use in combination with rifampin as treatment of choice since the 1980s (GIGUÈRE et al., 2011). Probably, this profile could be worse if rifampin was not used, since this combination reduces the likelihood of $\boldsymbol{R}$. equi resistance to either drug (PRESCOTT \& NICHOLSON, 1984). It is noteworthy that ERY resistance can drive to AZN and CLR resistance. The molecular mechanisms of macrolide resistance of $\boldsymbol{R}$. equi isolates have not been determined, but it is known that cross-resistance among macrolides is common (GIGUÈRE et al., 2011; MUSCATELLO, 2012); thus if an isolate is resistant to ERY probably will be also resistant to AZM and CLR.

BUCKLEY et al. (2007) evaluated $94 \boldsymbol{R}$. equi isolates from Ireland between 2000 and 2006 and demonstrated an increase from 0.2 to $0.5 \mu \mathrm{g} \mathrm{ml}^{-1}$ in the MIC values for ERY. In this regard, analysis of the distribution of resistant $\boldsymbol{R}$. equi isolates collected between 1997 and 2008 from different American states suggests that the prevalence of antimicrobial resistance to macrolide antimicrobials is increasing (GIGUÈRE et al., 2010). Differently, in this study it was not observed significant increase in the MIC values for isolates collected from 1991 to 2013 ( $\mathrm{P}>0.05)$. This finding can be associated with the mass macrolide treatment of foals with subclinical pulmonary lesions and, especially, the antimicrobial chemoprophylaxis against $\boldsymbol{R}$. equi foal pneumonia, common in other countries (GIGUÈRE et al., 2011; MUSCATELLO, 2011). However, for CLR, the clinical samples showed the major MIC values when compare with $R$. equi isolates from feces, soil and installations samples $(\mathrm{P}<0.05)$. This result is according to selection pressure hypothesis, since rhodococcosis is a chronic disease and repeated treatment can easily target to macrolide resistance (GIGUÈRE et al., 2010).

RIBEIRO et al. (2006) demonstrated strong efficacy of AZM against Brazilian $R$. equi isolates $\left(\mathrm{MIC}_{90}<1.5 \mu \mathrm{g} \mathrm{ml}^{-1}\right)$. Similarly, in the present study, it was observed $\mathrm{MIC}_{90}$ values between 0.5 and $1 \mu \mathrm{g} \mathrm{ml}^{-1}$, reinforcing the effectiveness of AZM in Brazilian isolates. Our results corroborate with MIC values observed by others studies, despite the timing among the publications to be more than 10 years (JACKS et al., 2003; CARLSON et al., 2010; RIESENBERG et al., 2013) (Table 1). 
Table 1 - Minimum inhibitory concentration (MIC) of three antimicrobial agents against $\boldsymbol{R}$. equi Brazilian isolates from clinical (n=15), feces $(\mathrm{n}=9)$, installations $(\mathrm{n}=5)$ and soil $(\mathrm{n}=15)$ samples.

\begin{tabular}{|c|c|c|c|c|c|c|c|c|c|c|c|c|c|c|}
\hline ATM & Source & $<0.03$ & 0.03 & 0.06 & 0.12 & 0.25 & 0.5 & 1 & 2 & $\mathrm{MIC}_{50} *$ & $\mathrm{MIC}_{90} *$ & $\mathrm{~S}$ & IS & $\mathrm{R}$ \\
\hline \multirow{4}{*}{ ERY } & Clinical & 0 & 0 & 1 & 2 & 7 & 2 & 3 & 0 & 0.25 & 1 & 80 & 20 & 0 \\
\hline & Feces & 0 & 0 & 0 & 0 & 2 & 3 & 4 & 0 & 0.5 & 1 & 73 & 27 & 0 \\
\hline & Installations & 0 & 0 & 0 & 1 & 3 & 0 & 0 & 1 & 0.25 & 2 & 93 & 7 & 0 \\
\hline & Soil & 0 & 0 & 0 & 1 & 2 & 8 & 4 & 0 & 0.5 & 1 & 73 & 27 & 0 \\
\hline \multirow{4}{*}{ AZM } & Clinical & 0 & 0 & 1 & 3 & 1 & 8 & 1 & 1 & 0.5 & 1 & 100 & 0 & 0 \\
\hline & Feces & 0 & 0 & 0 & 0 & 4 & 5 & 0 & 0 & 0.5 & 0.5 & 100 & 0 & 0 \\
\hline & Installations & 0 & 0 & 0 & 1 & 3 & 1 & 0 & 0 & 0.25 & 0.5 & 100 & 0 & 0 \\
\hline & Soil & 0 & 0 & 0 & 0 & 4 & 6 & 5 & 0 & 0.5 & 1 & 100 & 0 & 0 \\
\hline \multirow{4}{*}{ CLR } & Clinical & 3 & 2 & 4 & 4 & 2 & 0 & 0 & 0 & 0.06 & 0.25 & 100 & 0 & 0 \\
\hline & Feces & 5 & 0 & 2 & 2 & 0 & 0 & 0 & 0 & $<0.03$ & 0.12 & 100 & 0 & 0 \\
\hline & Installations & 1 & 3 & 0 & 0 & 1 & 0 & 0 & 0 & 0.03 & 0.25 & 100 & 0 & 0 \\
\hline & Soil & 10 & 1 & 3 & 1 & 0 & 0 & 0 & 0 & $<0.03$ & 0.06 & 100 & 0 & 0 \\
\hline
\end{tabular}

\footnotetext{
${ }^{*} \mathrm{MIC}_{50}$ and $\mathrm{MIC}_{90}$ were defined as the lowest concentrations of antimicrobials capable of inhibiting the growth of $50 \%$ and $90 \%$ of isolates, respectively.

$\mathrm{ATM}=$ antimicrobial, $\mathrm{SP}=$ susceptibility profile, $\mathrm{S}=$ sensitivity, $\mathrm{IS}=$ intermediate sensitivity and $\mathrm{R}=$ resistance

$\mathrm{S}:=2 \mu \mathrm{g} \mathrm{ml}^{-1}$ (AZM and CLR) and $=0.5 \mu \mathrm{g} / \mathrm{ml}(\mathrm{ERY}) ; \mathrm{R}:=8 \mu \mathrm{g} \mathrm{ml}^{-1}$ (AZM, CLR and ERY), IS: MIC values between the concentrations mentioned (breakpoints according to CLSI, 2009).
}

Although in other countries $\boldsymbol{R}$. equi macrolide resistance appears to be in a more advanced step, R. equi Brazilian isolates used here showed a large susceptibility profile, except against ERY, for which it was observed some resistance evidence due the intermediate sensitivity profile verified. In order to avoid this process, since the antimicrobials evaluated herein are the best rhodococcosis treatment options, it was highlighted the importance of microbiological culture and $\boldsymbol{R}$. equi antimicrobial susceptibility testing in vitro before beginning treatment.

\section{ACKNOWLEDGMENTS}

The authors acknowledge the financial support from Fundação de Amparo à Pesquisa do Estado do Rio Grande do Sul (FAPERGS) and National Council for Scientific and Technological Development $(\mathrm{CNPq})$ for the scholarship of Marcelo Luís Schwab and Bibiana Petri da Silveira.

\section{REFERENCES}

BUCKLEY, T. et al. Resistance studies of erythromycin and rifampin for Rhodococcus equi over a 10-year period. Veterinary Ireland Journal, v.60, n.12, p.728-731, 2007. Available from: $<$ http://www.ncbi.nlm.nih.gov/pmc/articles/PMC3113830/>. Accessed: Mar. 30, 2014. doi: 10.1186/2046-0481-60-12-728.

CARLSON, K.L. et al. Antimicrobial activity of Tulathromycin and 14 other antimicrobials againt virulent Rhodococcus equi in vitro. Veterinary Therapeutics, v.11, n.2, p.E1-E9, 2010.
Available from: <file://C:/Users/cliente/Downloads/VTX0610_ carlson.pdf>. Accessed: Jan. 20, 2014.

CLSI (CLINICAL AND LABORATORY STANDARDS INSTITUTE). Performance standards for antimicrobial disk and dilution susceptibility tests for bacteria isolated from animals. Approved Standard. 4.ed. Waye, Pennsylvania, USA, 2013. (CLSI document VET01-A4).

GIGUÈRE, S. et al. Determination of the prevalence of antimicrobial resistance to macrolide antimicrobials or rifampin in Rhodococcus equi isolates and treatment outcome in foals infected with antimicrobial-resistant isolates of $\boldsymbol{R}$. equi. Journal of the American Veterinary Medical Association, v.237, n.1, p.74-81, 2010. Available from: <http://avmajournals.avma.org/ doi/abs/10.2460/javma.237.1.74>. Accessed: Jan. 10, 2014. doi: 10.2460/javma.237.1.74.

GIGUÈRE, S. et al. Diagnosis, treatment, control, and prevention of infections caused by Rhodococcus equi in foals. Journal of Veterinary Internal Medicine, v.25, n.6, p.1209 1220, 2011. Available from: <http://onlinelibrary.wiley.com/doi/10.1111/ j.19391676.2011.00835.x/full>. Accessed: Apr. 01, 2014. doi: 10.1111/j.1939-1676.2011.00835.x.

JACKS, S.S. et al. In vitro susceptibilities of Rhodococcus equi and other common equine pathogens to azithromycin, clarithromycin, and 20 other antimicrobials. Antimicrobial Agents and Chemotherapy, v.47, n.5, p.1742-1745, 2003. Available from: $<$ http://aac.asm.org/content/47/5/1742.full.pdf + html $>$. Accessed: Dec. 20, 2013. doi: 10.1128/AAC.47.5.1742-1745.2003.

MONEGO, F. et al. Molecular characterization of Rhodococcus equi from horse-breeding farms by means of multiplex PCR for the vap gene family. Current Microbiology, v.58, p.399-403, 2009. 
Available from: <http://link.springer.com/article/10.1007/s00284009-9370-6>. Accessed: Jan. 20, 2014. doi: 10.1007/s00284-0099370-6.

MUSCATELlO, G. Rhodococcus equi pneumonia in the foal part 2 diagnostics, treatment and disease management. Veterinary Journal, v.192, n.2012, p.27-33, 2011. Available from: <http:// www.sciencedirect.com/science/article/pii/S1090023311002917>. Accessed: Jan. 20, 2014. doi: 10.1016/j.tvj1.2011.08.009.

PRESCOTT, J.F.; NICHOLSON, V.M. The effects of combinations of selected antibiotics on the growth of Corynebacterium equi. Journal of Veteterinary Pharmacology Therapeutics, v.7, p.61-64, 1984. Available from: <http://onlinelibrary.wiley.com/ doi/10.1111/j.1>. Accessed: Dec. 20, 2013. doi: 10.1111/j.13652885.1984.tb00880.x.
QUINN, P.J. et al. Corynebacterium species and Rhodococcus equi. In: QUINN, P.J.et al. (Eds). Clinical Veterinary Microbiology. London: Wolfe Publishing, 1994. p.137-143.

RIBEIRO, M.G. et al. Minimal inhibitory concentration of azithromycin in Rhodococcus qui strains isolated from foals. Arquivo Brasileiro de Medicina Veterinária e Zootecnia, v.58, n.6, p.1244-1246, 2006. Available from: <http://dx.doi. org/10.1590/S010209352006000600041>. Accessed: Jan. 20, 2014.

RIESENBERG, A. et al. MICs of 32 antimicrobial agents for Rhodococcus equi isolates of animal origin. Journal Antimicrobial Chemotherapy, v.24, p.1-5, 2013. Available from: <http://jac./content/early/2013/11/22/ja0>. Accessed: Feb. 14, 2014. doi: $10.1093 / \mathrm{jac} / \mathrm{dkt} 460$. 